\title{
Beyond Counterinsurgency: Why the Concept is Failing
}

\author{
Thomas Braun*
}

\section{Introduction}

The changing face of modern warfare is revealed nowhere more clearly than in asymmetric surroundings where traditional approaches do not succeed anymore. Military forces are encountering numerous opponents who no longer consist largely of identifiable combatants, but rather are irregular fighters who live among and within the population, making them extremely difficult to identify. Although uprisings and insurgencies are not new developments, the military's capacity to combat them was neglected in doctrinal thinking at the beginning of the twenty-first century. New trends and challenges and the rethinking of military combat operations, as well as the development of insights regarding a comprehensive approach, led to the re-creation of counterinsurgency doctrine. The U.S. Army/Marine Corps Field Manual 3-24, titled simply Counterinsurgency (hereafter, FM 3-24), was written during the most recent conflict in Iraq. This process was largely driven by General David Petraeus. But the United States' counterinsurgency strategy has shown disappointing results in Afghanistan, and critics are already calling for new approaches. ${ }^{1}$ Six years after the publication of FM 3-24 frustration is widespread that the current counterinsurgency approach in Afghanistan is not proving to be the panacea that it was promised to be. From the U.S. perspective, the topic becomes even more important, as counterinsurgency is "the strategy through which the United States has expended the greatest level of military resources since September 11, 2001."2

\section{Trends and Challenges in Contemporary Armed Conflict}

The prospect of a full-scale conventional war with joint operations in a state-on-state scenario has become less probable in the past twenty years, although the possibility cannot be ruled out completely. While the fundamental principles of war remain unchanged, the character of military engagements has changed significantly. Not only has the num-

Lieutenant Colonel (GS) Thomas Braun, Dipl.-Päd.(univ.), is an Air Force Officer with operational deployments to the Balkans and Sudan. An alumni of the Führungsakademie der Bundeswehr and of the George C. Marshall Center, Thomas Braun is currently serving on the Staff of the German Military Representative in the NATO Military Committee at NATO HQ in Brussels, Belgium. Besides NATO-Russia relations, he is focusing on NATO Capability Development and all pillars of NATO Common Resources. The expressed view in this article is strictly the personal opinion of the author.

1 David Wood, "Counterinsurgency Strategy not Working in Afghanistan, Critics Say," Politics Daily (11 January 2011), 1; available at www.politicsdaily.com/2011/01/11/counterinsurgencystrategy-not-working-in-afghanistan-critics-s/.

2 Baucum Fulk, "An Evaluation of Counterinsurgency as a Strategy for Fighting the Long War," Carlisle Paper (Carlisle, PA: Strategic Studies Institute, U.S. Army War College, March 2011), 1; available at http://www.strategicstudiesinstitute.army.mil/pubs/display.cfm?pubid=1052. 
ber of armed conflicts been declining since the end of the Cold War (to a low of only twenty-three armed conflicts in 2010), but the ratio of casualties has changed as well. ${ }^{3}$ In the beginning of the twentieth century, more than 90 percent of killed and wounded persons were combatants, and only 10 percent were civilians; this ratio has reversed completely nowadays, to 90 percent civilian casualties and 10 percent combatants. ${ }^{4}$ The opponent, whether an irregular fighter or terrorist, is no longer a 'combatant,' strictly speaking; making the challenge for military forces even greater is the fact that the opponent is hard to identify within the normal population. Examples include the Taliban in Afghanistan, or the pirates operating off the coast of Somalia. Such opponents are challenging for conventional military forces, since they do not obey or act according to the Law of Armed Conflict. Constraints or rules of engagement for military operations are not applicable to opposing forces such as irregular fighters. As state-on-state scenarios have become less probable, multiple definitions for different types of conflict have arisen, such as guerilla wars, revolutions, low-intensity conflicts, three-block wars, small wars, or asymmetric wars - a proliferation of nomenclature that illustrates both the diversity of conflicts and the difficulty of defining modern wars. ${ }^{5}$ But although history shows us that "irregular warfare is by no means only a modern phenomenon," it also bears out the general lesson that irregular warfare has most often been a secondary action to regular warfare. ${ }^{6}$ At present, irregular warfare is frequently the primary action of opposing elements, as they are normally not strong enough to oppose regular forces openly. In the past, in conflicts featuring state actors, either of the opposing sides could initiate a conflict, but in an insurgency only the insurgents may initiate a conflict, although the use of force might not be the first instrument at hand. ${ }^{7}$ This condemns regular military forces to simply playing a waiting game, because preemptive strikes against the population are not an option. Insurgencies may have multiple causes, most of which are primarily of a political (as opposed to military) nature. The main objective in current conflicts is to win the support of the population, which is a political challenge that is being ultimately pursued with military means. Therefore insurgencies are constantly engaged in a gradual transition from peace to war, and often an abrupt tipping point is not visible. With the challenges mentioned above, along with the effects of the privatization of military affairs and globalization in general, the whole military environment becomes more complex, and it is obvious that a pure military solution is actually no solution at all. Yet counterinsurgency is generally always regarded as an entirely military task, although the military aspect is only part of the overall picture.

3 Wolfgang Schreiber, "Kriege und bewaffnete Konflikte 2011," AKUF Analysen No.10 (Arbeitsgemeinschaft Kriegsursachenforschung, Universität Hamburg, December 2011), 1. Herfried Münkler, "Die neuen Kriege: Privatisierung und Kommerzialisierung kriegerischer Gewalt und Folgen," manuscript of lecture given in Berlin, 26 March 2003, 2.

5 James K. Wither, "Trends in Warfare," in Encyclopedia of Violence, Peace, and Conflict, Vol. 3, ed. Lester Kurtz (Oxford, UK: Elsevier, 2008), 24-26.

6 Ibid.

7 David Galula, Counterinsurgency Warfare: Theory and Practice (Westport, CT: Praeger Security International, Classics of the Counterinsurgency Era, 2006 [1964]), 3. 


\section{Evolution of Counterinsurgency as a Response to Contemporary Challenges}

With the unconventional challenges that coalition forces faced in Iraq and in Afghanistan in the first decade of the twenty-first century, a focus on low-intensity warfare was needed after the official war ended. The transition from traditional war fighting to the concept of counterinsurgency was a long and difficult path, as the U.S. Army found itself unprepared in Iraq in 2003 to engage in this unconventional type of campaign. Modern security challenges required 'new' answers, as conventional forms of military operations did not succeed anymore. David Galula underlined this complexity in his formulation that "a revolutionary war is 20 percent military action and 80 percent political," and referred to the political leadership as operating in a counterinsurgency scenario. ${ }^{8}$ Western nations were not prepared to fight insurgencies with the necessary level of endurance, and lacked the appropriate structures to conduct such a fight effectively. ${ }^{9}$ Especially on the doctrinal level, none of the major Western powers - the United States, Great Britain, France, and Germany — had anything updated in 2003 that could serve as a guide. ${ }^{10}$ Looking at historical lessons learned, British forces were regarded as being especially well prepared and experienced in fighting small wars, as their counterinsurgency doctrine had been rewritten in $1990 .{ }^{11}$ In 2003 , the problems facing coalition forces in Iraq and the Middle East fighting small wars had their roots in two distinct areas. First, there was a lack of experience in counterinsurgency operations in terms of experienced officers (the British had fought their last counterinsurgency operation in the Middle East in 1976, in Dhofar, and for the U.S. forces, Vietnam had been long forgotten in terms of counterinsurgency doctrine).${ }^{12}$ Second, there was a failure at the doctrinal level. Lessons learned from history were simply neglected in operational planning procedures during the Iraq campaign and in the initial phase of operations in Afghanistan. With the U.S. Army focusing on conventional warfare, it took them thirty years after losing the Vietnam War to rethink their concepts around irregular warfare. The challenges in Iraq made the U.S. request training from the British in irregular warfare, as the British had earned an excellent reputation for their success in the Malayan campaign. ${ }^{13}$ Following the experience in Iraq, with guidance from British officials and under the leadership of General David Petraeus, the revised U.S. Field Manual 3-24 Counterin-

\footnotetext{
Ibid., 63.

John Mackinlay and Alison Al-Baddawy, Rethinking Counterinsurgency, RAND Counterinsurgency Study, Vol. 5 (Santa Monica, CA: RAND Corporation, 2008), 2.

10 A German military counterinsurgency doctrine had been only available as a draft version in 2011, by that time not yet officially released.

11 James K. Wither, "Basra's not Belfast: The British Army, Small Wars and Iraq," Small Wars and Insurgencies 20: 3-4 (September-December 2009): 617.

12 Ibid., 616.

13 Ibid., 614.
} 
surgency was published in 2006. ${ }^{14}$ The creation of FM 3-24 and the coalition's initial successes due to the 'surge' in Iraq led to hopes that counterinsurgency would be the concept of the future, as some supporters of the concept see the future as mostly dominated by irregular war fighting. ${ }^{15}$

\section{Analysis of the Concept}

The concept of counterinsurgency as stated in FM 3-24 in its broadest definition is understood as a way to think about irregular warfare while remaining aware of the fact that counterinsurgency, "in the American mode, is but one small reflection of the much older, even ancient, practice of countering insurgents, or irregular enemies." 16 Gorka and Kilcullen continue to stress that the doctrinal principles of FM 3-24 were indeed not shaped by lessons learned, but derived from selected experiences during the past that have considered only a small subset of the many diverging forms of warfare. ${ }^{17}$ Evaluating the success of counterinsurgency operations is not easy, according to LieutenantColonel Paganini, the Director of the U.S. Army Counterinsurgency Center, who also refers to the importance of flexibility that is necessary in order to be constantly adaptive to modern challenges. ${ }^{18}$ Addressing the strengths of the concept and the weak spots that critics have identified as having led to the failure of counterinsurgency efforts in the current environment will eventually provide an answer to the question of whether the concept is failing or just needs adjusting. By focusing on the weaknesses, my intent here is to emphasize the need for alternatives without anticipating the final conclusion.

\section{Strengths}

The most important factor of the concept is its promotion of the fact that counterinsurgency is about popular support and governance, and that the military plays only one role out of many. Counterinsurgency is a complex and holistic system-of-systems approach that is deployed in order to ensure peace and stability within a region, preferably with an existing legitimate government. The "winning hearts and minds" approach is populationcentric, and is rooted in the assumption that it is more important to gain popular support than to kill one or two more insurgents.

The goal is to create an acceptable level of legitimacy in the local government so that success can be longer-lasting. One principle is to focus on political aims and political

14 U.S. Army/Marine Corps Counterinsurgency Field Manual, issue 3-24 (Washington, D.C.: Department of the Army Headquarters, December 2006).

15 Sebastian L.v. Gorka and David Kilcullen, "An Actor-centric Theory of War: Understanding the Difference Between COIN and Counterinsurgency," Joint Force Quarterly 60 ( $1^{\text {st }}$ Quarter 2011): 15; available at http://www.ndu.edu/press/coin-and-counterinsurgency.html.

16 Ibid.

17 Ibid.

18 Kristina Wong, "Counterinsurgency in Afghanistan: Is it Working?," ABC News (9 October 2011); available at http://abcnews.go.com/US/counterinsurgency-afghanistan-working/story? id=14694736. 
processes, while maintaining realistic goals. This fact is in theory a strength of the concept, but it needs to be approached from two sides. In theory, maintaining the primacy of the political dimension is important in order to generate public and legal support, but on the other hand the presence of a large number of deployed non-military actors can show the weakness of political will, or more accurately the lack of capabilities of the political actors. The incorporation of intelligence and information is another strength of the counterinsurgency concept, as it recognizes the priority of intelligence gathering and sharing in an effort to know the enemy. ${ }^{19}$ In order to locate, target, and oppose the enemy, sufficient intelligence is necessary. The holistic approach of the concept is aimed at the root causes within the population that have given rise to the insurgency, in order to counter these factors. After having forgotten how to fight small wars - or, as in the case of the U.S. Army, not being willing to think about it-it is vital to once again think about counterinsurgency as a necessary tool for the preparation and education of forces in order to sustain them in combat. In summary, counterinsurgency is a more tactical approach for the military that is adaptable to a wide range of circumstances, but which requires education and training in advance. At the same time, counterinsurgency is useful for generating the same goals for multiple players in a crisis region, as it unites the different approaches to countering insurgents and enhances the unity of effort. The concept itself allows all actors at all times to adapt the operations plan according to the necessities on the ground.

\section{Weaknesses}

A high-ranking Taliban leader made clear in late 2010 that "one of the main reasons for our popularity is the failure of this government." 20 This statement shows that the importance of supporting legitimate governance cannot be stressed enough before going on "capture-or-kill missions." But the focus on the local, regional, or national government in a crisis region needs to come from more sources than just the military. Although the military will often initially have more assets available in a crisis region that it can deploy in support of the government, governance itself remains a civilian task. During the process of evaluating FM 3-24, it became obvious that by looking at only a limited number of examples from Western nations in the twentieth century, the discussion of counterinsurgency approaches seemed somehow limited. In addition, this fact also limits our thinking and understanding of current and future challenges in small-war scenarios. ${ }^{21}$ Gorka and Kilcullen emphasize that "modern Western [counterinsurgency] theory is built on a handful of books based upon practitioner experiences in a handful of twentieth-century conflicts...."22 Although counterinsurgency as presented in FM 3-24 is far

19 Crispin Burke, Michael Few, and Clarke Prine, "Evolving the COIN Field Manual: A Case for Reform," Small Wars Journal (July 2011): 1; available at http://smallwarsjournal.com/jrnl/art/ evolving-the-coin-field-manual-a-case-for-reform.

21 Gorka and Kilcullen, "An Actor-centric Theory of War," 15.

22 Ibid.,15-16. 
more complex than had been previously thought, when viewed through a historical lens its presentation is limited to a narrow perspective: Iraq is not Malay or Ireland. It is important to consider that FM 3-24 as it is used currently offers the soldier a set of best practices and an easily referred to "check-list." But without recognizing that every insurgency is different from those that have come before, it is impossible to remember that every counterinsurgency campaign must be different as well. The length of operational tours is affecting the success of counterinsurgency operations. Building trust with locals takes time, but if operational deployments are only from four to six months long, ${ }^{23}$ it cannot be expected that an adequate level of knowledge and respect between the main players can develop. The short duration of deployments was one of the reasons behind the frequent strategy changes in Iraq, and undermined the relationship-building efforts of British military in the area of operations. ${ }^{24}$ In order to work closely with the local population or local decision makers, it is evident that a certain level of trust is needed. In this regard, the "Winning Hearts and Minds" approach was totally misunderstood. In a counterinsurgency scenario, it means that winning the support of the population might serve as a center of gravity for the overall aims of the mission, but that popularity or likeability among the people is not the aim. It is indeed necessary to use robust force in kinetic operations during a counterinsurgency campaign, but targets should be chosen carefully, keeping in mind the ultimate goal of building a legitimate and functional government. Current expectations derived from military operations in Iraq were too high, and were not transferable to the situation in Afghanistan - indeed, it is even disputed that the success in Iraq has resulted in the United States changing its approach toward counterinsurgency operations. ${ }^{25}$ The slow pace of process has a serious impact on the level of domestic public support. ${ }^{26}$ Counterinsurgency efforts take time and are very expensive, which creates pressure on political stakeholders, who are often up for reelection before a counterinsurgency campaign has run its course. Counterinsurgency is no replacement for a strategy. It is aimed mainly at the tactical and operational levels, but absolutely requires an overall strategy that does not consist only of short-term expectations. ${ }^{27}$ Knowing the weaknesses of the concept, Wood's demand is blunt: "Drop the hearts n' minds stuff. Go kill the enemy." ${ }^{28}$

23 British forces are usually sent to the field for six months, whereas German troops normally only deploy for four months, although taking the fact into consideration that trust building needs time there are flexible adjustments for deployments up to one year possible in Germany.

24 Wither, "Basra's not Belfast," 618.

25 David H. Ucko, "Counterinsurgency after Afghanistan: A Concept in Crisis," Prism 3:1 (National Defense University Press, Center for Complex Operations, December 2011): 4.

26 A successful fight against an insurgency usually requires anywhere from twelve to fifteen years, Gorka and Kilcullen, "An Actor-centric Theory of War," 17.

27 Mackinlay and Al-Baddawy, Rethinking Counterinsurgency, 62.

28 Wood, "Counterinsurgency Strategy not Working in Afghanistan," 1. 


\section{"Beyond COIN": Is Counterinsurgency the Right Answer for Current Conflicts?}

Lacking a coherent strategy, and considering the fact that every counterinsurgency campaign is different, it also may be that 'General Petraeus' counterinsurgency doctrine simply may not apply to Afghanistan." ${ }^{29}$ The rise and fall of the relevance of counterinsurgency was remarkably quick, but what are the alternatives? Currently the discussion supports an approach where the effort towards large-scale counterinsurgency operations is decreasing, while special forces are conducting a direct military engagement against remnants of Al Qaeda and Taliban forces that is defined as 'counterterrorism,' moving away from the costly civil-military approach of counterinsurgency. ${ }^{30}$ In addition, the U.S. public has become more wary of the engagement in Afghanistan after nearly ten years of operations there (with few concrete signs of success), which adds to the pressure of a strategic change. ${ }^{31}$ The counterterrorism concept supports a narrower and more precise approach to eliminating opposing elements, which is less costly than the comprehensive approach that a counterinsurgency effort embraces. A mixture of counterinsurgency and counterterrorism elements - a so-called "Counterterrorism Plus" operation-where "capture-or-kill" operations are conducted along with the protection of a few key population centers, seem to be a promising alternative. ${ }^{32}$

Generally, counterinsurgency is the right answer for most of the current conflicts in terms of planning and executing operations, as it offers a clear set of guidelines and best practices. But these efforts require time, money, dedication, and political support, and it is important to keep in mind that counterinsurgency is not the hoped-for panacea that was much praised when FM 3-24 was introduced. Currently, there seems to be a quiet transition from counterinsurgency to counterterrorism under way, a shift that is taking place already but is hardly noticed. The great benefit of this transition is that it offers political actors a way out of Afghanistan without being publicly embarrassed. Even with the transition to counterterrorism and the challenging security environment of the twenty-first century in mind, "beyond counterinsurgency" must always be simultaneously understood to mean "before counterinsurgency."

\section{Conclusion}

The challenging and threatening security environment is emerging hand in hand with a series of even more alarming developments, as military service times are being reduced, defense budgets are rapidly decreasing, and perceptions of threat levels are rising, as is the complexity of future risks and conflicts. But with respect to insurgencies, whatever is currently being done is essentially preparing for the "last counterinsurgency operation."

29 Ibid., 2.

30 Peter Rudolf, "War Weariness and Change in Strategy in U.S. Policy," SWP Comments No. 34 (German Institute for International and Security Affairs, October 2011): 2.

31 Wood, "Counterinsurgency Strategy not Working in Afghanistan," 1.

32 Rudolf, "War Weariness and Change in Strategy in U.S. Policy," 6. 
The limited scope of a few selected successful counterinsurgency operations has led to a false feeling of security in Iraq and Afghanistan. ${ }^{33}$ The Western powers chose the hard way to relearn the lessons of irregular warfare and to readapt to the challenges of the changing counterinsurgency scenario. Gorka and Kilcullen point out that "a single unified counterinsurgency doctrine is not possible, that there can be no universal set of best practices...." ${ }^{34}$ Therefore, the lessons learned and the best practices are being used well if they are being considered in planning future operations, but this effort always requires a local or regional perspective, as counterinsurgency in East Asia might not be the same as counterinsurgency in the jungles of Peru. Counterinsurgency as formulated in FM 324 offers a wide range of insights, best practices, and guidelines from former operations, but these rules need to be adapted with respect to specific, local challenges. They can be helpful in the planning and execution of campaign plans, but by themselves they do not constitute a strategy..$^{35}$ The lack of an overall strategy for either operations or for the political realm is evident, and cannot be masked by the application of good tactics. For modern fighting forces it is essential that they are capable of covering the whole spectrum of operations, from small wars or insurgencies to a full-scale conventional state-onstate war.

The concept of 'counterinsurgency' operations as set forth in FM 3-24 is the correct concept for small wars, but it needs a broader base of historical cases from which it can draw adaptations, recognizing that every counterinsurgency campaign is different, and the concept does not replace a comprehensive strategy with a realistic political aim. Etzioni correctly states "that if counterinsurgency is to work, it must be profoundly recast." ${ }^{36}$ Chances are currently low that any Western nation will dedicate such a large number of troops to any counterinsurgency scenario in the near future, as "counterinsurgency has not been a happy experience, and there will be no desire to prep for an encore." ${ }^{37}$ But the hard lessons learned in the past decade should not be buried again.

33 Andrew P. Betson, "Slow Learners: How Iraq and Afghanistan Forced Britain to Rethink COIN," Armed Forces Journal (November 2011): 41.

34 Gorka and Kilcullen, “An Actor-centric Theory of War," 16.

35 Ucko, "Counterinsurgency after Afghanistan," 11.

36 Amitai Etzioni, “Whose COIN?” Joint Force Quarterly 60 (1st Quarter 2011): 19.

37 Ucko, "Counterinsurgency after Afghanistan," 15. 


\section{Bibliography}

Betson, Andrew P.. "Slow Learners: How Iraq and Afghanistan Forced Britain to Rethink COIN ." Armed Forces Journal (2011).

Crispin, Burke, Few Michael, and Prine Clarke. "Evolving the COIN Field Manual: A Case for Reform." Small Wars Journal (2011).

David, Galula. Counterinsurgency Warfare: Theory and Practice. Westport, CT: Praeger Security International, Classics of the Counterinsurgency Era, 2006.

Fulk, Baucum. An Evaluation of Counterinsurgency as a Strategy for Fighting the Long War In Carlisle Paper . Carlisle, PA: Strategic Studies Institute, U.S. Army War College, 2011.

Gorka, Sebastian, and Kilcullen David. "An Actorcentric Theory of War: Understanding the Difference Between COIN and Counterinsurgency." Joint Force Quarterly 60 (2011).

Mackinlay, John, and Alison Al-Baddawy. Rethinking Counterinsurgency, RAND Counterinsurgency Study. Santa Monica, CA: RAND Corporation, 2008.

Schreiber, Wolfgang. Kriege und bewaffnete Konflikte 2011 In AKUF Analysen No. 10 . Arbeits-gemeinschaft Kriegsursachenforschung, Universität Hamburg, 2011.

Wither, James K.. "Basra's not Belfast: The British Army, Small Wars and Iraq." Small Wars and Insurgencies 20 (2009).

Wither, James. "Trends in Warfare." In Encyclopedia of Violence, Peace, and Conflict., 2008.

Wood, David. "Counterinsurgency Strategy not Working in Afghanistan, Critics Say." Politics Daily (2011). 